\title{
UPAYA PERLINDUNGAN HAK-HAK TERSANGKA TERHADAP KASUS PENYALAHGUNAAN NARKOTIKA DALAM PRA PERADILAN
}

\author{
${ }^{1}$ Desy Kartika Caronina Sitepu, SH,MH, ${ }^{2}$ Nelvitia Purba, SH, H.Hum, PhD \\ ${ }^{1}$ Fakultas Hukum Universitas Simalungun, ${ }^{2}$ Fakultas Hukum UMN Al-Washliyah Medan, \\ e-mail: Desysitepu22@gmail.com,nelvitiapurbaumn@gmail.com
}

\begin{abstract}
ABSTRAK
Penegak hukum ada kalanya di dalam melaksanakan tugasnya dan wewenangnya secara tidak bertanggung jawab dan melanggar terhadap kasus-kasus yang ditangani termasuk kasus penyalahgunaan narkotika. Hal ini dapat dibuktikan dengan adanya berita ataupun laporan yang sering memuat tentang seseorang yang disangka melakukan tindak pidana, di tahan melebihi batas waktu yang telah ditetapkan oleh KUHAP, ataupun adanya tindakan penahanan yang dilakukan oleh aparat penegak hukum tanpa disertai dengan surat penahanan yang jelas bahkan penahanan yang dilakukan tanpa prosedur yang benar. Analisis data yang dilakukan oleh penulis dengan menentukan isi dan makna daripada aturan hukum yang akan dijadikan pegangan dalam menyelesaikan masalah yang di kaji Setelah itu dilakukan pengumpulan data, selanjutnya diseleksi, diklasifikasi dan disusun dalam bentuk narasi yang kemudian disatukan dalam bentuk karya ilmiah. Dengan menggunakan metode deduktif yaitu penarikan kesimpulan yang ditarik dari sesuatu yang sifatnya umum yang sudah dibuktikan kebenarannya dan penelitian ini menghasilkan data deskriftif berupa pengumpulan tertulis maupun lisan yang berkaitan dengan penelitian ini yaitu penelitian kepustakaan dan penelitian lapangan yang dianalisis secara kualitatif. Mengawasi adanya tindakana upaya paksa yang dilakukan oleh aparat penegak hukum tersebut, maka KUHAP telah menciptakan lembaga Praperadilan. Adanya lembaga Praperadilan ini adalah bertujuan untuk tegaknya hukum dan perlindungan daripada hak-hak tersangka untuk mendapat perlindungan hukum dan perlindungan hak asasi tersangka tersebut di dalam proses pemeriksaan pada tingkat pemeriksaan, penyidikan dan penuntutan..
\end{abstract}

Kata Kunci: Praperadilan, Hak-hak tersangka,Penyidik,Melampau Wewenang

\section{PENDAHULUAN}

Penyalahgunaan Narkotika merupakan bahaya yang dapat menghambat kemajuan bangsa Indonesia dalam melaksanakan pembangunan di setiap sektor kehidupan. Dimana kita ketahui bahwa Indonesia sejak masa dekade 70-an belum lagi menjadi daerah yang menggiurkan bagi pemasaran narkotika. Pada saat itu, negeri ini hanya merupakan wilayah transit bagi barang-barang haram yang akan dikirim ke Australia atau ke Negara Asia Pasifik lainnya. Pada masa sekarang,
Indonesia sudah menjadi pasar yang menggiurkan bagi para pengedar narkotika. ${ }^{1}$ Bahkan di beberapa daerah termasuk yang ada di Sumatera Utara antara lain : Kabupaten Batubara suatu daerah darurat Narkoba ,hal ini terjadi karena banyaknya pulau-pulau kecil dimana pengawasan dari aparat pemerintah dalam hal ini polisi laut tidak sampai menjangkau untuk melakukan pengawasan ketat terhadap pulau-pulau ini. Dan tentunya siap hari mendengar yang diduga pemakai atau 
pengedar dari barang-barang haram ini dilakukan penangkapan.

Dan Permasalahan yang dihadapi saat ini adalah yang berkaitan dengan narkotika ini adalah bahwa Sumatera Utara menempati ranking ketiga setelah DKI Jakarta dan Kalimantan Timur dalam tingkat pemakai narkoba. $^{2}$

Pasal 127 ayat (1) huruf a UndangUndang Nomor 35 Tahun 2009 Tentang Narkotika menyebutkan bahwa Untuk setiap daripada penyalahgunaan Narkotika Golongan I bagi diri-sendiri dipidana dengan pidana penjara paling lama 4 tahun.sanksi pidana yang tertuju terhadap Narkotika Golongan I, sanksi selama 4 tahun.sanksi pidana yang tertuju terhadap Narkotika Golongan I, sanksi selama 4 tahun tersebut belum memenuhi batasan sanksi pidana yang menyebabkan dibiolehkannya dilakukan penahanan sebagaimana ketentuan dalam KUHAP Pasal 21 ayat (4) yang mengatur boleh dilakukannya penahanan terhadap tersangka atau terdakwa yang diduga melakukan tindak pidana dengan ancaman hukuman minimal 5 tahun atau lebih.

Di dalam kehidupan sehari-hari dengan begitu maraknya pelaku penyalahgunaan Narkotika ini di tengah-tengah masyarakat ada yang diduga melakukan penyalahgunaan narkotika namun sebenarnya tidak melakukan tindakan

\footnotetext{
2 Waspada, Anggota DPR RI Prihatin Sumut Ranking 3 Pemakai Narkoba, 28 Pebruari 2015

${ }^{3}$ Rizqi Nurul Fadhilah, Penahanan Dalam Sistem Peradilan Pidana Terhadap Tersangka Tindak Pidana
}

kejahatan tersebut ,namun hanya tuduhan saja yang sama sekali tidak melakukannya, hal ini tiada lain sengaja di jebak oleh temantemannya untuk mencemarkan namanya.

Keberadaan Hukum Pidana sangat diperlukan sekali dalam kasus penyalah gunaan Narkotika, hal ini disebabkan karena Hukum Pidana adalah merupakan salah satu bagian dari hukum yang menunjukkan adanya pernbedaan dengan hukum-hukum lainnya yaitu aturan hukum yang bersifat mengikat yang terdapat aturan-aturan didalamnya harus dipenuhi oleh masyarakat untuk menjamin agar norma-norma ada di dalam masyarakat terpenuhi. Hal ini bertujuan menciptakan ketertiban hukum, kepastian hukum serta keserasian dalam kehidupan. ${ }^{3}$ Hal ini adalah merupakan bagian dari penegakan hukum yang dilakukan untuk mewujudkan cita-cita hukum dalam rangka menciptakan keadilan dan kedamaian dalam kehidupan yang bermasyarakat, berbangsa dan bernegara sesuai dengan tujuan pembangunan Nasional Indonesia yaitu untuk mencapai suatu keadaan masyarakat Indonesia yang adil dan makmur secara merata baik materiil maupun spiritual yang berdasarkan kepada Pancasila dan UUD $1945 .{ }^{4}$

Asas praduga tidak bersalah (Presumption Of Innocence) mengatur bahwa setiap orang yang disangka, ditangkap, ditahan

penyalahgunaan Narkotika, Law Journal Syiah Kuala Vol 2 (1) April 2018

${ }^{4}$ Hartono, penyidikan Dan Penegakan Hukum Pidana Melalui Pendekatan Hukum Progresif Sinar Grafika, Jakarta, 2010

Jurnal Ilmiah "Advokasi" Vol. 07. No. 02 September 2019 
atau di depan pengadilan, wajib dan dianggap

tidak bersalah sebelum adanya putusan pengadilan yang menyatakan kesalahannya dan mempunyai kekuatan hukum yang tetap. ${ }^{5}$

Di dalam kenyataan sehari-hari sering juga ditemui adanya tindakan yang sewenangwenang yang berupa upaya paksa daripada penegak hukum tersebut yang tentunya dalam hal ini melanggar HAM daripada tersangka, dilakukan dengan kekerasan dan penyiksaan sehingga dalam hal ini maka di dalam peradilan yang diatur dalam Kitab UndangUndang Hukum Acara Pidana (KUHAP) yang disebut dengan Pra Peradilan yang berfungsi untuk mengontrol dari tindakan aparat penegak hukum agar tidak melampaui wewenangnya. ${ }^{6}$

Upaya-upaya tersebut yang dikemukakan di atas sebagai alasan untuk menemukan dan mengakui terhadap orang yang bersangkutan memang melakukan tindak pidana yang dituduhkan kepadanya.Padahal dalam kenyataannya yang terjadi tidak semua orang yang diduga melakukan tindak pidana memang yang bersangkutan memang melakukan perbuatan tindak pidana tersebut.

Praperadilan adalah merupakan suatu kontrol terhadap tindakan penyidik dalam menjalankan tugas dan wewenangnya dalam proses peradilan pidana apakah telah dilakukan dengan benar atau tidak, atau dapat

\footnotetext{
5 Emi Widhayanti, Hak-Hak tersangka/terdakwa Di Dalam KUHAP, Liberty, Yogyakarta,2008.

${ }^{6}$ R.Soeparmono, Praperadilan Dan Penggabungan Perkara Ganti Kerugian Dalam KUHAP, Bandung, Mandar Maju, 2003
}

juga dikatakan apakah wewenangnya yang dilimilki oleh polisi tersebut umum dilaksanakan telah melanggar hak-hak tersangka atau tidak.Lembaga ini diberikan sebagai sarana pengawasan dengan maksud untuk menegakkan hukum, keadilan dan kebenaran secara horizontal dan pengawasan secara vertikal tentunya diadakan oleh masingmasing atasan badan tersebut. ${ }^{7}$

Praperadilan dapat diajukan sebagai akibat daripada tersangka yang merasa hakhaknya diabaikan, sebagai akibat daripada berbagai tindakan yang sewenang-wenang atau penyalahgunaan kewenangan daripada aparat penegak hukum. Praperadilan diajukan oleh tersangka disebabkan masih terdapat kemungkinan kesalahan manusia dalam proses penanganan perkara dan untuk meminimalkan serta mencegah terjadinya kesalahan tersebut maka adanya tahapan tatacara yang terbuka dan dapat diuji oleh pihak-pihak yang yang terkait.

\section{RUMUSAN MASALAH}

1. Bagaimanakah peranan daripada Praperadilan dalam upaya perlindungan terhadap hak-hak tersangka kasus yang diduga penyalahgunaan Narkotika dalam pemeriksaan di tingkat penyidikan?

\footnotetext{
${ }^{7}$ Kadri Husin Dan Budi Rizki Husin, Sistem Peradilan Pidana Di Indonesia, Sinar Grafika, Jakarta,2016
} 
2. Faktor-faktor apa saja yang menjadi penghambat terhadap perlindungan hak-hak tersangka di dalam Praperadilan?

\section{METODE PENELITIAN}

\section{Sifat Dan Jenis Penelitian}

Penelitian ini adalah bersifat deskriftif analisis yaitu penelitian yang menggambarkan menelaah, menjelaskan, serta menganalisa peraturan perundang-undangan yang berkaitan dengan tujuan daripada penelitian ini. Tujuan dalam penelitian ini deskritif adalah dengan menggambarkan secara tepat sifat-sifat daripada individu, keadaan, gejala atau kelompok tertentu untuk menentukan frekuensi atau penyebaran suatu gejala atau frekuensi adanya hubungan tertentu antara gejala dan gejala lain dalam masyarakat. ${ }^{8}[8]$

Adapun yang merupakan sumber data yang digunakan di dalam penelitian ini yaitu data primer dan data sekunder.Data primer yang diperoleh dalam hal ini adalah diperoleh langsung dari pihak-pihak yang terkait dalam hal hai ini kepada yang diduga tersangka pelaku kejahatan penyalah-gunaan Narkotika. Sedangkan Sumber Data Sekunder adalah berasal dari buku-buku literatur yang berkaitan dengan masalah yang dibahas, majalahmajalah, jurnal-jurnal, dokumen resmi, serta perturan perundang-undangan yang ada kaitannya dengan permasalahan yang di bahas.
Teknik Pengumpulan Data yang digunakan untuk memperoleh data sekunder adalah dengan cara studi kepustakaan untuk ini dilaksanakan antara lain :

a. Studi Kepustakaan (Library Research)

Di dalam studi Kepustakaan ini adalah untuk mencari konsep-konsep, teori-teori, pendapat-pendapat atau penemuanpenemuan yang berhubungan erat dengan pokok permasalahan. Kepustakaan ini dapat berupa peraturan perundang-undangan, karya ilmiah para sarjana, jurnal-jurnal dsb.

b. Studi Lapangan (Field Research).

Yaitu menghimpun data dengan melakukan wawancara dengan penyidik sebagai informasi yang berhubungan dengan penelitian ini, yang berkaitan dengan kasus yang di bahas dalam penelitian ini, yang dijadikan data pendukung atau data pelengkap dalam melakukan penelitian ini.

Analisis data yang dilakukan oleh penulis dengan menentukan isi dan makna daripada aturan hukum yang akan dijadikan pegangan dalam menyelesaikan masalah yang di kaji ${ }^{9}$ Setelah itu dilakukan pengumpulan data, selanjutnya diseleksi, diklasifikasi dan disusun dalam bentuk narasi yang kemudian disatukan dalam bentuk karya ilmiah. ${ }^{10}$ Dengan menggunakan metode berpikir deduktif yang ditarik dari sesuatu yang sifatnya umum yang sudah dibuktikan

\footnotetext{
8 Kontjaraningrat, Metode-metode Penelitian Masyarakat, Gramedia, Jakarta,2007
}
9 Zainuddin Ali, Metode Penelitian Hukum,Cetakan ke 5, Sinar Grafika, Jakarta,2014
${ }^{10}$ Soerjono Soekanto, Pengantar Penelitian Hukum, UI Press, Jakarta, 2008


kebenarannya dan yang ditunjukkan untuk sesuatu yang sifatnya khusus. Yang kemudian ditarik kesimpulan $^{11}$ sebagai prosedur penelitian yang menghasilkan data deskriftif berupa pengumpulan tertulis maupun lisan yang berkaitan dengan penelitian ini yaitu penelitian kepustakaan dan penelitian lapangan yang dianalisis secara kualitatif.

\section{PEMBAHASAN}

I. Peranan daripada Praperadilan dalam upaya perlindungan terhadap hak-hak tersangka kasus yang diduga penyalahgunaan Narkotika dalam pemeriksaan di tingkat penyidikan

Perlindungan adalah merupakan suatu bentuk apresiasi dan implementasi aparat penegak hukum dan juga aparat keamanan untuk menjaga rasa aman baik psikis maupun fisik, terhadap orang atau subjek hukum dari intimidasi, gangguan dan teror serta kekerasan dari pihak manapun yang diberikan pada tahap penyelidikan, penyidikan maupun pemeriksaan di sidang pengadilan. ${ }^{12}$

Praperadilan dimaksudkan adalah merupakan mekanisme kontrol terhadap kemungkinan dari tindakan sewenangwenang dari penyidik maupun penuntut umum dalam melakukan penangkapan, penggeledahan, penyitaan ,penyidikan, penuntutan, penghentian penyidikan dan penghentian

11 Sedarmayanti Dan Syarifuddin Hidayat, Metodologi penelitian, Mandar Maju, Bandung, 2002.

12 Lilik Mulyadi, Hukum Acara Pidana Normatif, Teoritis Praktek Dan Permasalahannya, Alumni Bandung, 2007 penuntutan baik yang disertai dengan permintaan ganti kerugian dan atau rehabilitasi ataupun tidak. ${ }^{13}$

Perlindungan hukum bagi tersangka dalam proses penyidikan kasus penyalahgunaan Narkotika sebagai jaminan perlindungan dari perundang-undangan akan adanya pengakuan hak-haknya yang harus diakui dan dihormati oleh aparat penegak hukum dalam hal ini adalah penyidikan kepolisian dimana hak-hak daripada tersangka tersebut tidak boleh diabaikan.

Adapun yang merupakan bentuk daripada perlindungan yang diatur dalam KUHAP tersebut antara lain :

1. Penerapan Upaya Paksa Yang Memperhatikan Daripada Hak-Hak Tersangka

Dalam hal ini KUHAP menginginkan daripada proses peradilan pidana yang mengembangkan paradigma bahwa : Setiap warga negara yang menjadi tersangka tidak lagi dipandang sebagai objek namun harus merupakan subjek yang mempunyai hak dan kewajiban. ${ }^{14}$

Dalam menerapkan upaya paksa ini yaitu :

a. Penangkapan

Dalam hal melakukan penangkapan ini Polisis harus memperhatikan tata cara yang diatur dalam KUHAP.

b. Penahanan
${ }^{13}$ Saiman Luthan dkk, Praperadilan Di Indonesia Dalam Teori Dan Prakteknya,Institute For Criminal Justice Reform,2014

14 Patra M. Zen, Panduan Bantuan Hukum Di Indonesia : Pedoman Anda Memahami Dan Menyelesaikan Masalah Hukum,YLBHI,Jakarta,2007 
Di dalam melakukan Penahanan ini terhadap seorang tersangka harus mempunyai dasar yang jelas.Penyidik harus dapat mengefisiensikan waktu untuk membuat BAP sehingga dapat memberikan perlindungan kebebasan seorang tersangka dan lamanya waktu penahanan yang sia-sia.

2. Perluasan Wewenang Lembaga PraPeradilan

Inspirasi lahirnya Lembaga Praperadilan adalah bersumber pada adanya hak yang memberikan jaminan yang fundamental terhadap HAM khususnya hak yang berkaitan dengan kebebasan dan kemerdekaan.Pemberian hak ini dilakukan dengan surat perintah yang dikeluarkan oleh Pengadilan yang bertujuan untuk menjamin pulihnya hak seseorang atas perampasan serta pembatasan hak kebebasan dan kemerdekaannya.

Oleh karena itu dapat dikemukakan bahwa Lingkup Pra Peradilan sangat sempit sebagaimana yang diatur dalam ketentuan Pasal 77 KUHAP yang mengemukakan :Ada tiga hal yaitu :

a. Sah atau tidaknya Penangkapan.

b. Sah atau tidaknya Penahanan

c. Sah/tidaknya penghentian penyidikan/penuntutan.

Oleh karena itu Lembaga Praperadilan yang ada sekarang hanya bersifat administratif dan tidak fundamental menjadi lembaga penjamin atas pelanggaran hak seorang tersangka.

Barda Nawawi mengemukakan bahwa perlindungan hukum yang perlu mendapat perhatian antara lain :

a. Perlindungan daripada perbuatan-perbuatan anti sosial yang merugikan dan membahayakan seseorang.

b. Perlindungan hukum terhadap sifat-sifat yang berbahaya daripada seseorang.

c. Perlindungan terhadap penyalahgunaan sanksi/reaksi daripada penegak hukum maupun warga masyarakat pada umumnya

d. Perlindungan terhadap keseimbangan atau keselarasan berbagai kepentingan dan nilai yang terganggu sebagai akibat adanya kejahatan. ${ }^{15}$

II. Faktor-faktor Apa Saja Yang Menjadi Penghambat Terhadap Perlindungan HakHak Tersangka Di Dalam Praperadilan Sebagaimana diketahui bahwa Praperadilan adalah merupakan daripada lembaga di Indonesia dalam kehidupan penegakan hukum, yang pada hakekatnya adalah merupakan suatu sistem, dimana hal ini dikarenakan dalam proses peradilan pidana di Indonesia terdiri dari tahapan-tahapan yang merupakan satu kesatuan yang utuh yang tidak dapat dipisahkan.

Tahapan-tahapan dalam proses peradilan pidana tersebut merupakan suatu rangkaian 
dimana tahap yang satu mempengaruhi tahap yang lainnya.

Proses daripada peradilan pidana di Indonesia tersebut memiliki kewenangan untuk melakukan tindakan penyelidikan dan penyidikan yang terdapat pada tingkat kepolisian, yang memiliki kewenangan untuk melakukan daipada penuntutan ada pada tingkat kejaksaan, dan kewenangan untuk mengadili dalam pemeriksaan di sidang pengadilan ada pada hakim.

Adapun yang merupakan faktor penghambat dalam pelaksanaan Praperadilan ini antara lain :

a. Praktek Praperadilan Yang Masih Kurang Berjalan

Hal ini terjadi disebabkan karena praktek yang berkaitan dengan masalah praperadilan ini masih sangat jarang terjadi dan kebanyakan kasus-kasus tersebut jarang yang dikabulkan atau permohonannya ditolak termasuk kasus penyalahgunaan Narkotika ,salahsatu kasusnya Hoksan (51) ditangkap Satresnarkoba di Polres Tuban atas kasus narkoba telah mengajukan Praperadilan di PN setempat, sidang Praperadilan didaftarkan oleh kuasa hukum pria yang memiliki usaha loundry tersebut di Jalan Basuki Rahmat Tuban. Sidang Praperadilan pemohon sudah diputus gugur, hal ini disebabkan karena pelaku telah lebih dahulu diputus sebagai terdakwa. $^{16}$
Berdasarkan kenyataan tersebut terutama akibat kurangnya pengertian pemohon di dalam meahami ruang lingkup peradilan.Maka bisa saja hal ini dapat membebaskan daripada aparat penegak hukum yang telah berbuat sewenang-wenang dan melanggar aturan hukum yang berlaku, sehingga dapat dikatakan bahwa lembaga praperadilan ini masih belum berperan sebagaimana yang diharapkan dan sesuai dengan KUHAP.

Yahya Harahap mengemukakan bahwa :

a. Berada dan merupakan kesatuan yang melekat pada Pengadilan Negeri sebagai lembaga pengadilan hanya dijumpai pada tingkat Pengadilan Negeri sebagai satuan tugas yang tidak terpisah dari Pengadilan Negeri.

b. Praperadilan bukan berada diluar atau disamping maupun sejajar dengan Pengadilan negeri tetapi hanya merupakan divisi dari Pengadilan Negeri.

c. Administrasi yustisial, personil, peralatan dan finansial bersatu dengan Pengadilan Negeri dan berada di bawah pimpinan serta pengawasan dan pembinaan daripada Ketua Pengadilan Negeri.

d. Tata laksana fungsi yustisialnya adalah merupakan bagian daripada fungsi yustisial daripada Pengadilan Negeri itu sendiri.

2 Perbedaan Dasar Dari pada Pertimbangan Hakim Dalam menjatukan Putusan Hal ini disebabkan karena beberapa

\footnotetext{
${ }^{16}$ Tribun Jatim, Upaya Praperadilan Terdakwa Kasus Narkoba Di Putus Gugur PN Tuban,Kuasa Hukum Sebut Ada Kejanggalan, https/jatim/tribunnews.com/09/9/19
} 
perkara yang diajukan dalam Praperadilan banyak yang mempunyai dasar permohonan dan jenis perkara yang hampir sama.Namun didalam hal ini penetapan sidang yang berbeda-beda dan keadaan yang seperti setelah dicari penyebabnya karena hakim-hakim yang memeriksa permohonan Praperadilan tersebut masih sering mempunyai persepsi yang berbeda-beda terhadap kaus-kasus yang di proses di dalam lembaga Praperadilan.

\section{b. Dibatasinya Waktu Yang Singkat Dalam} Pemeriksaan Perkara Praperadilan

Di dalam prosedur terhadap pemeriksaan Praperadilan ini yaitu pemohon dalam hal ini (tersangka, keluarga pihak yang berkepentingan atau kuasa hukumnya) akan mengajukan permintaan atau permohonan pemeriksaan Praperadilan kepada Ketua Pengadilan Negeri yang berwenang yang daerah kuasa hukumnya meliputi domisili (kantor) aparat penegak hukum (penyidik/penuntut umum) yang diajukan sebagai pemohon sebagaimana yang diatur di Pasal 79,80 dan 81 KUHAP.

Dengan di batasinya waktu dalam proses beracara merupakan masalahdalam Praperadilan.Berdasarkan kepada Pasal 82 ayat (1) Huruf c ditentukan bahwa pemeriksaan yang dilakukan secara cepat dan selambat-lambatnya 7 Hari Hakim sudah harus menjatuhkan putusannya. Jika proses

\footnotetext{
${ }^{17}$ Devi Kartika Sari dkk, Analisis Yuridis kedudukan Hakim Pemeriksa Pendahuluan Sebagai Upaya Pembaharuan Lembaga Praperadilan Dalam Sistem Peradilan Pidana
}

beracara perkara Praperadilan tersebut tidak selesai dalam masa 7 (Tujuh) hari maka perkara Praperadilan yang dianggap gugur dengan demikian perkara pokok sudah mulai diperiksa oleh pengadilan negeri.Dibatasinya waktu tersebut mengacu pada salah satu asas dalam sistem peradilan pidana yaitu asas peradilan cepat, sederhana dan biaya ringan. ${ }^{17}$ Sebagaimana yang dikemukakan di atas bahwa secara prosedural tidak ada masalah atau hambatan yang dihadapi oleh hakim ketika memproses perkara untuk di Praperadilankan ,namun ketika hakim di dalam menjalankan tugas dalam hal ini maka masalah yang dihadapi antara lain :

a. Mengenai masalah tenggang waktu yang diatur bahwa di dalam proses lembaga praperadilan merupakan pemeriksaan secara cepat dan selambat-lambanya 7 hari,dalam hal ini Hakim harus sudah menjatuhkan putusan sehingga mau tidak mau Hakim harus secara tegas dan berkomitmen kepada pihak pemohon maupun pihak termohon dalam waktu 7 (tujuh) hari harus selesai dan sudah ada putusan.

b. Di dalam proses Praperadilan ini benar masuknya perkara ini akan tetap di proses dalam proses beracaranya sama seperti perkara perdata,

Berdasarkan hal-hal yang dikemukakan di atas maka upaya
Di

Indonesia,Fak.Hk.Univ.Brawijaya.https//media.nelti.co m.media 
penanggulangan yang dilakukan sebagai perlindungan untuk tersangka dalam memberikan keterangan secara bebas pada tingkat penyidikan antara lain :

1. Polisi Yang Propesional Dan Berintegrasi Tinggi

Dalam hal ini agar tidak terjadinya pelanggaran-pelanggaran terhadap hak-hak tersangka dalam proses pemeriksaan penyidikan harus memakai penyidik yang profesional dalam menjalankan tugasnya.Dan penyidik harus mengetahui tentang aturan hukum yang terdapat dalam KUHP dan KUHAP .Profesionalisme penyidik tidak hanya dari segi kualitas tetapi juga dri segi kuantitasnya.

Disamping itu peningkatan dan pemgembangan pengetahuan dapat dilaksanakan melalui Pendidikan dan pelatihan baik dalam lingkungan Kepolisian maupun berbagai bentuk pelatihan lainnya untuk meningkatkan profesionalisme.

\section{Menjunjung Tinggi HAM}

3. Peran Serta Masyarakat Dan Sosialisasi Terhadap Masyarakat Dan Tersangka

Masyarakat awam secara umum banyak yang tidak tahu dan kurang pemahamannya akan adanya aturan perundang-undangan dalam hal ini KUHAP.Aparat penegak hukum dalam hal ini perlu untuk memasyarakatkan Hukum Acara Pidana tersebut dan diharapkan dengan adanya Sosialisasi ini maka masyarakat dapat mengetahui hak dan kewajibannya dan masyarakat yang sudah mengetahui tentang peraturan hukum tersebut mau tidak mau akan tunduk terhadap aturan yang berlaku tersebut karena manfaat dari hukum tersebut sangat besar.

4. Adanya Sarana Dan Prasarana Serta Fasilitas Yang Memadai

Agar Pihak Kepolisian di dalam menjalankan tugasnya dengan baik dan berjalan lancar untuk itu lembaga kepolisian tersebut harus memiliki sarana dan fasilitas yang memadai, baik dari segi perlalatan maupun pendanaan yang cukup.Tanpa di dukung oleh sarana dan fasilitas yang memadai akan sulit tercapai daripada suatu tujuan yang hendak diperoleh demi terwujudnya suatu kinerja kepolisian yang dapat membuat masyarakat percaya akan loyalitas dan totalitas dari kepolisian tersebut.

\section{KESIMPULAN}

1. Lembaga Praperadilan merupakan salah satu sebagai upaya terhadap perlindungan hak-hak tersangka dalam pemeriksaan di tingkat penyidikan untuk memberikan perlindungan hukum untuk selanjutnya dapat diajukan kepada Penuntut Umum, hak untuk memberikan keterangan secara bebas tanpa tekanan dari pihak manapun.Perlindungan bagi tersangka kasus penyalahgunaan narkotika dalam proses penyidikan yang dilakukan oleh aparat penegak hukum dapat dilakukan Praperadilan apabila ada penyimpangan hukum. 
2. Faktor-faktor penghambat terhadap perlindungan daripada hak-hak tersangka ini dalam praktek Praperadilan di antaranya adalah : Praktek Praperadilan yang masih kurang berjalan, dibatasinya waktu yang singkat dalam pemeriksaan perkara Praperadilan.Upaya yang dilakukan untuk menanggulangi hambatan ini adalah antara lain : Penegak Hukum Yang Profesional, Menjunjung Tinggi HAM ,Sosialisasi Dan Peran Serta Masyarakat, serta Penyediaan Sarana Dan Prasarana Yang Memadai.

\section{DAFTAR PUSTAKA}

Barda Nawawi, Polisi Sebagai Penegak Hukum Masalah-Masalah Hukum,UNDIP Semarang,2008

Devi Kartika Sari dkk, Analisis Yuridis kedudukan Hakim Pemeriksa Pendahuluan Sebagai Upaya Pembaharuan Lembaga Praperadilan Dalam Sistem Peradilan Pidana Di Indonesia,Fak.Hk.Univ.Brawijaya.https/ /media.nelti.com.media

Emi Widhayanti, Hak-Hak tersangka/terdakwa Di Dalam KUHAP, Liberty, Yogyakarta,2008.

Forum, Virus Jahat Bernama Narkotika, 30 Desember 2001.

Hartono, penyidikan Dan Penegakan Hukum Pidana Melalui Pendekatan Hukum Progresif Sinar Grafika, Jakarta, 2010
Kadri Husin Dan Budi Rizki Husin, Sistem Peradilan Pidana Di Indonesia, Sinar Grafika, Jakarta,2016

Kontjaraningrat, Metode-metode Penelitian Masyarakat, Gramedia, Jakarta,2007

Lilik Mulyadi, Hukum Acara Pidana Normatif, Teoritis Praktek Dan Permasalahannya, Alumni Bandung, 2007

Patra M. Zen, Panduan Bantuan Hukum Di Indonesia : Pedoman Anda Memahami Dan Menyelesaikan Masalah Hukum,YLBHI,Jakarta,2007

R.Soeparmono, Praperadilan Dan Penggabungan Perkara Ganti Kerugian Dalam KUHAP, Bandung, Mandar Maju, 2003

Rizqi Nurul Fadhilah, Penahanan Dalam Sistem Peradilan Pidana Terhadap Tersangka Tindak Pidana penyalahgunaan Narkotika, Law Journal Syiah Kuala Vol 2 (1) April 2018

Saiman Luthan dkk, Praperadilan Di Indonesia Dalam Teori Dan Prakteknya,Institute For Criminal Justice Reform,2014

Soerjono Soekanto, Pengantar Penelitian Hukum,UI Press,Jakarta,2008

Sedarmayanti Dan Syarifuddin Hidayat, Metodologi penelitian, Mandar Maju, Bandung,2002.

Tribun Jatim, Upaya Praperadilan Terdakwa Kasus Narkoba Di Putus Gugur PN Tuban,Kuasa Hukum Sebut Ada Kejanggalan, https/jatim/tribunnews.com/09/9/19

Waspada, Anggota DPR RI Prihatin Sumut Ranking 3 Pemakai Narkoba, 28 Pebruari 2015

Zainuddin Ali, Metode Penelitian Hukum,Cetakan ke 5, Sinar Grafika, Jakarta,2014 